\title{
Major cucumber diseases and the crop immunity
}

\author{
S.V. Bondarenko ${ }^{1}$, S.V. Stankevych ${ }^{1 *}{ }^{\circledR}$, A.V. Matsyura ${ }^{2}{ }^{\circ}$, L.V. Zhukova ${ }^{1}{ }^{1}$, \\ I.V. Zabrodina ${ }^{1}{ }^{1}$, M.M. Rysenko ${ }^{1}{ }^{1}$, L.V. Golovan 1, O.V. Romanov ${ }^{1}{ }^{1}$,

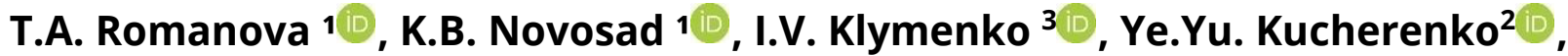 \\ A.M. Zviahintseva ${ }^{2}$
}

\author{
${ }^{1}$ V.V. Dokuchaev Kharkiv National Agrarian University, v. Dokuchaevske, Kharkiv region, 62483, Ukraine \\ ${ }^{2}$ Altai State University, Barnaul, Russian Federation \\ ${ }^{3}$ V.Ya. Yuryev The Plant Production Institute of NAAS, Kharkiv, 61060, Ukraine \\ *Corresponding author E-mail: sergejstankevich1986@gmail.com
}

Received: 12.12.2020. Accepted 26.01.2021

\begin{abstract}
In Ukraine, cucumber (Cucumis sativus Linneus) annually occupies about $20 \%$ of the total area of all vegetable crops sown in the open ground or 52.6 thousand hectares. The main reason that significantly reduces the quantitative and qualitative indicators of this vegetable crop's main valuable economic traits is the high incidence of commercial crops with diseases, especially downy mildew (Pseudoperonospora cubensis (Berk \& M.A. Curtis) Rostovtsev). Since 1985 in Ukraine, this cucumber disease in the open ground on nonresistant varieties has continuously had intense development, in some years the development - by the type of epiphytotic. Simultaneously, the shortage of commercial yield of this vegetable crop due to the defeat of this disease under the field conditions can reach the level of 50-80\% or more, seed loss - 25-70 \%. One of the main reasons for significant losses of commercial yield and seeds of gherkin cucumber under the conditions of its cultivation in the open ground is recognized as the high susceptibility of samples to some diseases, particularly downy mildew (Pseudoperonospora cubensis (Berk. \& M.A. Curtis) Rostovtsev). Unfortunately, this problem has remained relevant for Ukraine over the past few decades. So, obtaining the initial material of a gherkin cucumber with a harmonious combination in the genotypes of a complex of various valuable economic characteristics (yield, quality, resistance to diseases, chemical substances content, suitability for various types of processing) and creating a modern competitive, innovative product (variety, hybrid) on its basis remains a relevant and priority task for domestic agricultural science at present. At the same time, scientists have proved that introducing complex (integrated) systems into production, which expect the biologization of protection with its transfer to an ecological and economic basis, is recognized as the most promising today. We suggested using resistant varieties (hybrids) in such integrated systems that provide the highest economic effect.
\end{abstract}

Keywords: cucumber, diseases, prevalence, harmfulness, phytopathological complex, immunity, signs of long-term stability

\section{Introduction}

Cucumber (Cucumis sativus Linneus) belongs to the genus cucumber (Cucumis) of the pumpkin family (Cucurbitaceae Juss.). In the world, the area where this vegetable crop is grown annually occupies up to 9 million hectares (Sanwen Huang et al., 2009). In Ukraine, cucumber is also one of the main crops among vegetables, which is grown annually in both open and frame areas in various soil and climatic zones on areas of up to 50 thousand hectares (Bolotskih, 2002; Yarovij, 2006). When developing the cucumber classification, scientists considered the similarity of different samples by morphological traits, suitability for growing in specific climatic zones, and several other botanical (approbatory) traits (Sokolov, 2003).

Developed by A.I. Filov (Gorova \& Yakovenko, 2001), the classification of this vegetable crop is divided into seven subspecies: 1. Wild-growing subspecies (C. sativus ssp. agrestis Gab.). Small leaves with sharply marked lobes, small fruits, incredibly green color, cylindrical, very bitter. It grows in the northern regions of India in a wild state.

2. Himalayan subspecies (C. sativus ssp. himalaicus Fil.), including Indian Bohairic and Himalayan hollow. They have tiny branched stems, small spherical fruits up to $5 \mathrm{~cm}$ in diameter. Plants are almost bush-shaped, early ripening, fruits turn yellow very quickly.

3. Indo-Japanese subspecies (C. sativus ssp. indo-japonicus Fil.), which was formed under conditions of tropical and subtropical climates. The plants are solid, dark green, the fruits are large, with small or medium tubercles and complicated pubescence, with black (Indian) or white (Japanese) spikes. Varieties of this subspecies, especially Japanese ones, demand breeding as carriers of a complex of resistance genes to the most common diseases. 
4. Chinese subspecies (C. sativus ssp. chinensis Fil.). Plants are solid, with long runners and large leaves. The fruits are long, often curved, sickle-formed and serpentine. This subspecies is used in breeding when creating greenhouse varieties, early ripening and cold-resistant forms.

5. West-Asian subspecies (C. sativus ssp. occidentaliasiaticus Fil.), varieties of which have solid plants, large stems, small or medium-sized leaves. This ecotype is characterized by high adaptability to the continental climate conditions; plants combine heat and cold resistance in their genotype, fruits with thick skin can only be used in salads.

6. European-American subspecies (C. sativus ssp. europaeo-americanus Fil.). Plants of medium strength, with medium or small leaves. The fruits are small or medium-sized, with tubercles or rough. This subspecies includes most cucumber varieties grown in Ukraine and other regions of the world.

7. Hermaphrodite-flowered subspecies (C. sativus ssp. hermafhroditus Fil.), which is characterized by the formation of hermaphrodite flowers instead of female ones. The ovary is half-low, a turban is formed on the fruit. Pubescence is simple. Varieties of this subspecies are widely used in hybrid breeding.

According to the botanical description, cucumber is an annual herbaceous plant. The fruits of this vegetable crop are valued for their high taste, aroma, and various enzymes that promote digestion. They contain (in terms of $100 \mathrm{~g}$ of raw matter): sugar $1.5-$ $2.0 \%$, protein - about $1 \%$, vitamin C - 10-16 mg, vitamin PP - $0.2 \mathrm{mg}$, carotene $-0.1 \mathrm{mg}$. Cucumbers are superior to radishes in thiamine - red beet and common onion in terms of riboflavin content. Besides, cucumbers' iodine content is higher than that of potatoes, onions, and most other vegetable crops. Fruits are consumed in fresh, canned, and salted forms (Autko, 2004). Cucumber fruits' consumption improves appetite and the absorption of other foods due to the enzymes necessary for better absorption of B1 group vitamins. These alkaline salts reduce the acidity of gastric juice and are recommended for kidney and liver diseases. Cucumber juice is useful for rheumatic diseases, strengthens heart and blood vessels, has an antisclerotic effect, improves memory, and the high potassium content helps remove water from the human body, regulates and facilitates the work of the heart. Also, cucumber (juice) is widely used in cosmetology (Mamchur, 1988).

By weight, cucumber fruits are divided into tiny (weight less than 50 g), small (from 50 to 100 g), medium (101-200 g), large (201-400 g), and huge (over $400 \mathrm{~g}$ ). The taste qualities of the fruit (good, medium, bad) depend not only on the chemical composition but also on the consistency of the pulp (crunching, semi-dense, dense, coarse), the thickness of the skin (thin, thick), the bitterness content in the fruit (strong, absent) and the specific aroma (strong, weak or absent). By the duration of the growing season, cucumber varieties and hybrids are divided into early ripening, which begins to bear fruit 32-48 days after sowing in the open ground (Gherkin type), medium early ripening (50-55 days), and late-ripening (56-70 days) (Blinova, 2005; Nalobova, 2005).

Due to the global climate changes, the cultivation of varieties and hybrids of gherkin cucumbers (early ripening) has become attractive in commercial vegetable growing in Ukraine. Their main advantages, in comparison with samples of the semi-late and medium ripening group, is the genetically controlled size of the Gherkin fruit - no more than $12 \mathrm{~cm}$, the compact habitus of the plant (with short runners), the maximum commercial yield on irrigation -19-23 t/ha (with twice-repeated crop rotation), with drip irrigation - 45-50 t/ha (Avtorskie semena...., 2008).

We aimed to review the long-term resistance of gherkin to major diseases under different conditions and cultivation technologies, features of a phytopathological complex of gherkin, and gene complex (immunity) for resistance to major diseases.

\section{Results}

The theoretical and practical significance of protracted resistance trait of gherkin cucumber to the main diseases under various conditions and growing technologies.

Cropping capacity and quality of gherkin cucumbers strongly depend on the technology of its cultivation - varieties (hybrids) do not tolerate large doses of mineral fertilizers, need stable soil moisture supply, are severely damaged by pests and diseases, and significantly reduce productivity in case of late harvesting. Simultaneously, varieties and hybrids of gherkin-type cucumber over the past 7-10 years still took a leading position in the rating of domestic producers of fresh and processed vegetable production. Their main advantage is many ovaries and gherkins, small fruits-gherkins with high pickling qualities and high commercial cropping capacity (Avtorskie semena...., 2008).

One of the essential measures to increase the production of this vegetable crop is to increase its yield by breeding new highyielding varieties and hybrids, developing more advanced industrial cultivation technologies, one of the basic elements of which is a comprehensive system for protecting commercial crops from diseases, pests, and weeds (Alekseeva, 1984; Autko, 2004; Nalobova, 2008). Until 1985, the sowing area under cucumber in Ukraine was about 70 thousand hectares, but today, due to the substantial annual spread of downy mildew, they have decreased to 40 thousand hectares (Mihajlov, 1992; Litvinov, 2011). Under the conditions of the research region, downy mildew of cucumber acquired an epiphytotic character in 1989-1990, when only 2.07-2.36 t/ha of this crop was obtained from spring-summer film greenhouses in July, and summer commercial crops completely died from the disease (Chaban, 1993).

A sharp increase in losses of cucumber's commercial products due to losses from diseases became very relevant for many countries of the world during this period (Babadoost et al., 2004). As noted by G.I. Yarovyj, A.V. Kuleshov, and O.M. Batova (Yarovij et al., 2010), who analyzed the data of 1995-2005, downy mildew on cucumber under the conditions of the region of conducting research had a spread of 9-55\% (on average for years at the level of 27.8\%) with the degree of plant damage of $2-$ $27 \%$ (on average for years at the level of $14.5 \%$ ). Thus, in 1996, producers of commercial cucumber in the United States spent more than 120 million dollars on means for crops protection against downy mildew, which sharply reduced production profitability (Ojiambo, Paul \& Holmes, 1997). Earlier, back in the 80-90 years, scientists from different regions of the world found 
that downy mildew and cucumber affect more than 70 different plant species of the genus Cucumis. The disease became widespread in central Europe on cucumbers in 1984, virtually destroying this crop's crops (Grinko \& Zherdeckaya, 1991).

Spores of the pathogen showed a high ability to survive at relatively low soil temperatures in winter and active mycelium - the ability to be preserved in nature for quite a long time, which is established by systematic studies for many regions of the world (Efimov et al., 1978; Shetty, 2002; Rai, 2008). Up to $80 \%$ of all cucumber crops in Ukraine were varieties of Nezhinsky local and Nezhinsky 12 of Nezhinsky variety type (Petrenko \& Poznyak, 2007). The most distinct and precious consumer difference of varieties selected on the genetic basis of this variety type were very high pickling qualities and morphological and biometric traits of the commercial product: small (11-12 cm long) green fruit, thin, tender skin of green fruit, dense pulp with small cells, complicated black pubescence, thoughtful expression of ribs and furrows in young fruits, medium or small seed case, high taste qualities of processed products (Gorova \& Yakovenko, 2001; Bolotskih, 2002). Despite significant breeding achievements, after 1985 , the disease's global epiphytotic spread made cucumber cultivation in the former USSR unprofitable. Since this period that breeding work began in Ukraine, Belarus, Moldova, and other republics of the USSR to create varieties and hybrids of open ground cucumber of a new generation - primarily with protracted high resistance to the primary diseases, especially downy mildew, on the background of the maximum possible genetic improvement of several other valuable traits (Efimov et al., 1978; Prosalkova, 1994).

At the same time, breeders were faced with the task of combining as much as possible in the newly created varieties (hybrids) such characteristics as a friendly yield, a long period of fruiting (gherkins), high pickling fruits qualities, early ripening, resistance to the main diseases, in particular downy mildew (Gavrish, 2001).

Therefore, for further work with resistance trait to some diseases, particularly to downy mildew, samples of cucumber of Far Eastern selection were involved in the breeding process, where work was already carried out to create initial resistant forms of cucumber (Vitchenko \& Meleshkina, 1991). This happened by introducing cucumber's genetic potential originating from Japan, China, Vietnam, and India resistant to downy mildew and other diseases into domestic breeding (Gorova \& Yakovenko, 2001; Skripnik \& Lopotun, 2003).

In cucumber breeding for resistance to the primary diseases, it was found out that the focus on creating varieties and hybrids of cucumbers only to improve the yield indicators and quality of gherkins significantly limits the choice of sources and donors of resistance to the main diseases. Without the introduction of a sufficient variety of small genes (gene complexes) into the newly created genotype, which makes it possible to control resistance to the main diseases under the field conditions as much as possible, breeding in this direction is ineffective or doomed to failure (Nalobova, 2005). As a summary, it was stated that such a limited number of cucumber samples resistant to this disease led to a high uniformity of mass crops in the former USSR, which contributed to the rapid and intensive development of some phytopathogens, in particular the causative agent of downy mildew in significant areas (Gorohovskij, 2002; Blinova, 2005; Nalobova, 2005).

As noted above, in Ukraine, downy mildew has been registered annually on commercial crops for many years. According to various literary sources, the shortage of yield ranges from 50 to $100 \%$ in individual years (Sergiyenko, 2003). Thus, according to the State Plant Protection Inspectorate of the Ministry of Agrarian Policy and Food of Ukraine (Markov, 2010) in 2008, downy mildew on cucumber was recorded in June on more than a third of commercial crops. Only dry, hot weather in the second half of the growing season restrained its development in most areas where this vegetable crop is grown. At the same time, it was found that the most favorable weather conditions for the development and spread of downy mildew on cucumber crops annually develop in Transcarpathian, Zaporizhzhia, Dnipropetrovsk, Poltava, Kharkiv, and some other regions, where the damage rates of grown samples ranged from 42-100\% with a degree of damage from 10 to $45 \%$.

Considering the problematic ecological situation in Ukraine and the fact that cucumbers of Gherkin type are widely used in nutrition in a fresh form, the use of chemicals on this vegetable crop starts from the period of mass fruiting prohibited. This proves that breeding in the direction of creating resistant varieties is recognized today as the most radical means of globally protecting cucumber plants from diseases. However, we need to have information about the composition of natural populations of pathogens, their space, and time changes to successfully solve such breeding programs' problems. This process is long and should be constant, but production already needs real effective measures to regulate the prevalence of diseases and reduce cucumber yield losses from them (Bailey et al., 1992; Prosalkova, 1994; Skripnik, 2000; Adam, 2010).

Today, world and domestic producers of vegetable products solve this problem with integrated protection systems. They represent an ideal combination of biological, agrotechnical, breeding-genetic, chemical and organizational, and economic measures aimed at the most effective and ecologically justified neutralization of the negative effects of biotic stress factors of various origins on plants (Chaban et al., 2000; Autko, 2004; Bilik \& Kulyeshov, (2006). In the 90s, the scientific community admitted that humanity needs to learn how to organically manage agroecosystems by in-depth knowledge of general and specific rules of their formation and functioning. First of all, it was found out that both factors of immunity and methods for determining the necessity and timeliness of applying protection measures of different origins play a leading role in ensuring the natural self-regulation of artificial plant coenosis.

Simultaneously, it is primarily recommended to make changes in the ratio of varieties by increasing the share of sustainable varieties' growth (Chulkina \& Chulkina, 1995; Kirichenko \& Petrenkova, 2012). All protection measures should be carried out taking into account regional long-term and short-term forecasts, which will allow developing environmentally-oriented protection systems for each region of growing of a particular product (Chumakov, 1973). This harmonious combination of the above factors makes it possible to stop the increase in the use of pesticides, which will slow down the growth of pesticide environmental pollution (Kartashov \& Kazakova, 1988; Stancheva, 2005). At the same time, scientists have proved that introducing complex (integrated) systems into production, which expect the biologization of protection with its transfer to an ecological and economic basis, is recognized as the most promising today (Robaka, 2001). It is separately noted that it uses resistant varieties (hybrids) in such integrated systems that provide the highest economic effect (Wu, 1994). 
Peculiarities of the formation of a phytopathological complex of a cucumber of Gherkin type and gene complexes (immunity) by the resistance to the main diseases

The analyzed literature sources allowed us to establish a general and zonal list of open-ground cucumber diseases in the research region and globally (Yarovij et al., 2010). We determined that diseases such as downy mildew, powdery mildew, fusarium wilt, angular bacterial spot disease, and anthracnose are always present on cucumbers under open ground in the above list conditions (Mihajlov, 1992; Nalobova, 2004; Litvinov et al., 2011). At the same time, we noted that the selection of varieties resistant to these diseases is impossible without a thorough study of the long-term and seasonal peculiarities of their pathogenesis, biology of the main pathogens, and the nature of the formation of trophic connections with the plant, analysis of the influence of weather conditions on the intensity of these processes (Nalobova, 19984 Maryutin et al., 2010).

For the first time and most fully, the composition of many cultivated plants diseases, including cucumber, on the European part of the former USSR in 1929 was described by A.A. Yachevsky (Yachevskij, 1929).

Analysis of domestic literature has shown that the most common and harmful diseases of cucumber in the open and frame area are downy mildew, powdery mildew, anthracnose, fusarium wilt, and angular bacterial spot disease (Bondarenko, 2011; Bondarenko, 2012; Bondarenko, \& Solodovnik, 2012; Bondarenko, 2013; Bondarenko, Chernenko, \& Sergienko, 2013; Chernenko et al., 2013, Chernenko, Sergienko \& Bondarenko, 2014).

Downy mildew or peronosporosis of cucumbers (English - Downy Mildew of Cucurbits). This disease's causative agent is the fungal organism Pseudoperonospora cubensis (Berk. \& M.A. Curtis) Rostovtsev. It belongs to the kingdom Chromista (fungal organisms), the division Oomycota, the class Oomycetes, the order Peronosporales, the family Peronosporaceae, and the genus Pseudoperonospora (Garibova \& Lekomceva, 2005). In the international mycological literature, this disease's causative agent's basic name is Pseudoperonospora cubensis (Berk. \& M.A. Curtis) Rostovzev (Garibova \& Lekomceva, 2005). The international universal disease code is PCU (Zitter et al., 1996).

In addition to this name, in the scientific literature, this cucumber disease's causative agent for specific diagnostic symptoms has been described at various times under such names - Peronospora cubensis Berk. \& M.A. Curtis, in Berkeley (1868), Plasmopara cubensis (Berk. \& M.A. Curtis) Humphrey (1891), Peronospora atra Zimm. (1902), Pseudoperonospora tweriensis Rostovzev (1903), Pseudoperonospora cubensis var. tweriensis Rostovzev (1903), Plasmopara cubensis var. tweriensis (Rostovzev) Sacc. \& D. Sacc.(1905), Plasmopara cubensis var. atra (Zimm.) Sacc. \& D. Sacc. (1905), Peronoplasmopara humuli Miyabe \& Takah. (1905), Pseudoperonospora celtidis var. humuli Davis (1910), Plasmopara humuli (Miyabe \& Takah.) Sacc. (1912), Pseudoperonospora humuli (Miyabe \& Takah.) G.W. Wilson (1914), Peronospora humuli (Miyabe \& Takah.) Skalický.According to the type of nutrition, this pathogen belongs to typical classical biotrophic organisms (Brunelli \& Dawi, 1987; Gorohovskij, 2005). For the first time, downy mildew on cucumber in the open ground was discovered in Central America in Cuba in 1868, later (1888) - in Japan, and later, in 1889 - in North America. At the beginning of the twentieth century, downy mildew was recorded on cucumbers throughout Europe and East Africa, Brazil, and the Java Peninsula (Naumov, 1931).

Today, downy mildew of cucumber (pumpkin crops) in the open ground is widespread on all continents and geographical zones of cultivation - in the countries of Western, Central and Eastern Europe, Asia, Africa, North America, the Far and Middle East (Yakubickaya et al., 1987; Skripnik \& Lopotun, 2003). At one time, for the first time, the mass defeat of cucumber crops by downy mildew, except for Ukraine and the former republics of the USSR, was simultaneously observed in significant, radically different soil and climatic conditions in different European countries (Czechoslovakia (Laser et al., 1988); Germany (Mende \& Krumdein, 1986), Italy (Brunelli \& Dawi, 1987), Hungary (Summer \& Rhafar, 1987), Austria (Bedlan, 1986), Sweden (Forsberg, 1986), Switzerland (Varady \& Ducort, 1985) and Greece (Jeorgopoulos \& Skylakakis, 1986). According to literary reports, this disease mainly affects cucumber plants, melon, less often - watermelon, vegetable marrow, and other pumpkins. First, symptoms of downy mildew appear on cotyledon or real leaves. When plants in the field are affected, round or angular spots are formed on real cucumber leaves and quickly increase in size. With the angular shape of the spots, the disease is often mistaken for bacteriosis. In wet weather, spots on the leaf's underside are covered with a grey-purple coating of sporulation of the pathogen. Gradually, the spots increase in size and subsequently cover the entire leaf blade. Such leaves quickly turn brown, dry up and crumble (Kupalova \& Bolotskih, 1989).

The harmfulness of this disease in the open ground is very high - within a few days, especially in the presence of favorable weather conditions for the pathogen's development, it can lead to the complete death of cucumber crops. In wet and relatively warm weather, the causative agent of the disease forms many zoospores that spread by air currents and in the presence of drip-liquid moisture on the surface of plants, within 4-6 hours (night dew, rain, fog, watering) germinate, damage and re-infect the plant (Skripnik \& Lopotun, 2003; Nalobova, 2005; Walters et al., 2005).

Mathematical analysis of 10-year data under conditions of the region of conducting research revealed a negative connection between the amount of precipitation and the spread of the disease $(B=-0.69)$ and the tendency to reduce its development. The result of these studies was the fact of establishing a significant negative effect of increasing air temperature $(B=-1.57$ and 2.59) and positive effect of air humidity $(B=0.68$ and 2.07) on the dynamics of downy mildew development in agrocenoses (Yarovij, Kulyeshov \& Batova, 2010). Different researchers associate the somewhat atypical dependence of this moisture-loving phytopathogen on the amount of precipitation with the nature of their falling out during the period when the disease develops rapidly. Light precipitation, downpours during the day, and high temperatures do not provide protracted moisture to plants, and, as a result, do not contribute to the spread of the disease (Zherdeckaya, 1990; Gorohovskij, 2002; Yarovij, Kulyeshov \& Batova, 2010).

In contrast, it was found that excessive precipitation washes away the propagules of this phytopathogen from plants. So, for the development of downy mildew in cucumber agrocenosis, moderate precipitation, the presence of dew, air humidity of more than $70 \%$ are favorable - because these factors ensure the preservation of moisture on plants for more than 4-5 hours, which is essential for activating and accelerating the pathological process. Other scientists also emphasize that the intensity of the 
spread and development of this disease is closely interrelated with hydrothermal conditions, in which the presence of drop moisture on the leaves is crucial. The optimal air temperature for the fungus development is $18 . . .22^{\circ} \mathrm{C}(\mathrm{Zherdeckaya,} 1990$; Maryutin et al., 2010).

This phytopathogenic organism's development cycle in the natural environment is represented by endogenous mycelium and two types of spores: asexual (zoospores) and sexual (oospores). This pathogen's endogenous mycelium is branched, with eggshaped, pear-shaped haustoria, formed on cucumber plants throughout the growing season, causing their repeated reinfection. The type of lesion is passive. This phytopathogen is preserved during the inter-vegetation period: mycelium - in seeds, oospores - in infected plant remnants (Mihajlov, 1992; Garibova \& Lekomceva, 2005). Asexual sporulation of the fungus zoosporangiophores with zoosporangia (conidia), sexual - oospores. Zoosporangiophores are collected in bundles of 2-7 pieces, coming out through the torn cuticle with terminal branches extending at right angles. Zoosporangia are ellipsoidal, ovate, with a papillary tubercle at the apex, greyish or purple, sometimes brown, measuring 20-28 × 16-20 microns. Oospores are spherical, yellowish, 36-42 microns in diameter. Infection of plants occurs with the help of zoospores that come out of zoosporangia. Zoosporangia need drop moisture to germinate. Zoospores germinate by forming a tube through which this pathogen enters the plant through the stomata (Zitter, Hopkins, \& Thomas, 1996). This phytopathogen forms several generations of conidial sporulation during the growing season, providing a high reproduction rate and rapid epiphytotic spread. At the same time, it is noted that the optimal temperature for germination of zoosporangia and oospores is $15 \ldots 20{ }^{\circ} \mathrm{C}(\mathrm{Dhillon}$ et al., 1999). Some researchers also found that this disease is represented in field agrocenoses of cucumber by simple races or their combinative complex mixture in the world and Ukraine. However, research in this area has more general biological and evolutionary significance than practical or applied (Lebeda \& Widrlechner, 2003; Mitchell et al., 2011; Cohen \& Rubin, 2012).

In the presence of drop moisture on the plants, the infection can pass within 2 hours. From the moment of penetration of the fungus into the host plant's tissues to the appearance of the first disease symptoms, an incubation period passes, depending on weather conditions and varietal characteristics, ranging from 3 to 13 days (Forsberg, 1986). Also, it was reported that losses from this disease directly depend on plant development stages: the earlier the infection process occurs, the higher the production loss (Markov, 2010).

The appearance of primary foci of downy mildew at the beginning of the flowering phase under local conditions most often led to plants' complete death in significant areas even before the first harvest of commercial products. Severely affected plants grew brown and dried up, and only the remains of leaf petioles were retained on the shoots. The absence of leaves delayed the setting and development of fruits, and fruits that managed to form to marketable sizes did not have a typical "cucumber" taste, became wilted, the color of their skin was pale green (Efimov, Sklyarevskaya \& Olhovskaya, 1978; Timchenko \& Mihajlov, 1989). Earlier, it was already noted that if weather and climatic conditions contribute to developing this disease, the commercial yield of commercial cucumber can decrease even by 80-100 \% (Mihajlov, 1992). In Ukraine, due to the very strong (by the type of epiphytotic) nature of the development of this disease in 1985, the duration of the cucumber fruiting period was reduced to $1-$ 2 weeks, and in some places, the complete death of crops was recorded even before it began (Skripnik \& Lopotun, 2003). This disease covers significant areas of crops and can cause mass death of plants as early as 8-10 days from the beginning of the pathological process, having an expression in severe damage to leaf apparatus, shedding of the ovary, yellowing, and partial or complete wilting of fruits (Alekseeva, 1984; Strajstar, 1991). So, first of all, the harmfulness of this disease is manifested in a significant decrease in the assimilation surface of the leaf apparatus. With a weak degree of damage, the amount of chlorophyll decreases to $53 \%$, with an average - to $42 \%$, with a strong - to $13.3 \%$. Simultaneously, irreversible changes occur in the plant's protein complex with a gradual decrease in the synthesis of protein nitrogen, monosaccharides, and its complete cessation of complex sugars synthesis (Granke \& Hausbeck, 1995; Gorohovskij, 2005; Lindenthal, 2005).

From the literature sources, a complex of small (minor) genes that recessively control cucumber resistance to the disease is known: $d m$ - (downy mildew resistance), $d m-1$ (downy mildew resistance-1), $d m-2$ (downy mildew resistance-2), $d m-3$ (downy mildew resistance-3) (Gorbatenko, Holodnyak \& Shvartau, 2011).

As scientists note, even today, the system of measures to protect cucumbers from downy mildew is very limited. The use of various methods, including crop rotations, fertilizers, and chemical and biological means of protection, to prevent limiting the spread of this disease is, unfortunately, ineffective (Zitter et al., 1996; Babadoost et al., 2004).

At the same time, it is necessary to consider that cucumber fruits (the main product of consumption) are used not only in processed form but also in fresh. Thus, the use of chemical means of plant protection in the critical, from a phytopathological point of view, a period of their development (fruiting period) is minimal (Efimov et al., 1978; Mihajlov, 1992; Colucci \& Wehner, 2006; Celetti \& Roddy, 2011).

The most effective method of protecting cucumber crops from downy mildew today is considered to be growing in field crop rotations an assortment of varieties and hybrids with protracted high resistance. At the same time, it is recognized that this type of resistance can reduce both the volume of use of chemical and biological protection products and the multiplicity of treatments for cucumber plants of Gherkin type, which will positively affect the increase in the profitability of commercial production of this vegetable crop (McGrath, 2001; Sergiyenko, 2003; Nalobova, 2005; Chaudhry et al., 2009). Some authors define such diseases as powdery mildew, angular bacterial spot disease, or bacteriosis, fusarium wilt, and anthracnose to the list of less common but annually potentially dangerous cucumber diseases when it is grown in the open ground of the designated region of Ukraine (Yurina, 1984; Yarovij, Kulyeshov \& Batova, 2010). Cucumber powdery mildew (English - Powdery Mildew of Cucumber). The causative agent is the fungus Erysiphe cichoracearum DC. $f$. cucurbitacearum Poteb. It belongs to the class Ascomycetes, order Erysiphales, family Erysiphaceae, genus Erysiphe Link. The international universal disease code is Gc (ex Ec) (Zitter, Hopkins \& Thomas, 1996).

The disease is widespread on cucumbers in protected and open ground in all regions of its cultivation. It also affects vegetable marrow, pumpkin, melon, and other pumpkin plants in all development phases, starting with cotyledon leaves. A sharp increase 
in infection 10-20 days after the appearance of the first symptoms of this disease significantly reduces the growing season of plants, which is accompanied by a noticeable shortage of general and commercial yield (Zitter et al., 1996; Babadoost et al., 2004).

The disease manifests itself in separate white powdery spots on the upper surface of the leaves and subsequently on the lower one. With a firm lesion, the leaves and stems are covered with a complete powdery coating - the mycelium of this fungus. The mycelium of the fungus forms haustoria, with the help of which it penetrates the plant cell. Conidiophores are formed on mycelium's hyphae, on the limbs of which chains of oval conidia are separated (Mihajlov, 1992; Sokolov, 2003). During the growing season of plants, the disease is spread by conidia. At the end of the growing season, small spots appear on the mycelium (powdery coating), first yellow, then brown - wintering fruit bodies of the fungus (cleistothecia). According to the description of cleistothecia E. cichoracearum f. cucurbitacearum - spherical, 80-150 microns in diameter with a simple or branched appendix apex. Bags of 5-15 pieces in cleistothecia size 58-90 × 30-50 microns, with a short leg. As a rule, the spores are ellipsoidal or rounded, measuring 20-30 × 10-20 microns, two per bag (Cohen, 1977; Zherdeckaya, 1990).

Spores that affect cucumbers in the current year's crop rotation germinate in late spring and summer from overwintered cleistothecia. Affected leaves and stems of plants quickly turn brown and dry out. The yield and quality of cucumber fruits are reduced very much (Wu, 1994; Lebeda \& Urban, 2004). The development of the disease is promoted by sharp fluctuations in temperature and humidity and insufficient solar insolation of plants (Zitter, Hopkins \& Thomas, 1996). At the same time, depending on the specific combinative combinations of weather and climatic factors, powdery mildew in agrocenoses of openground melons (cucumber, melon) acts as a direct antagonist of downy mildew, primarily due to various requirements for ecological factors that form the mechanisms of the harmfulness of these diseases (Wehner \& Shetty, 1997). Conidia of the causative agent of this disease germinate best and infect plants at consistently high air humidity. The optimal temperature for plant damage by this pathogen is $16-20^{\circ} \mathrm{C}$. With an increase in temperature above $20^{\circ} \mathrm{C}$, the development of the disease is significantly inhibited. In some (cool and humid) years, powdery mildew can reduce the yield of cucumbers under open ground conditions by 30-45 \% (Medany, Wadid \& Abou Hadid, 1999). In the list of genes that control cucumber resistance to disease are noted the following: pm-1 (powdery mildew resistance-1), pm-2 (powdery mildew resistance-2), pm-3 (powdery mildew resistance-3), and $p m-h(s, p m)$ (powdery mildew resistance expressed by the hypocotyl) (Adam, 2010).

Today in the world and in Ukraine, there is an objective need to breed cucumber hybrids of open and especially frame areas with protracted complex resistance to diseases such as downy mildew (Pseudoperonospora cubensis Rostow) and powdery mildew (Erysiphe cichoracearum DC). This trait allows reducing the cost of growing them primarily by reducing the frequency of plant treatments with pesticides. Simultaneously, the created hybrids must be high-yielding and have high taste and technological qualities of fruits (Nalobova, 2008; Chistyakova, \& Biryukova, 2012).

Fusarium wilt of cucumber (English - Rot of Cucumber; Wilt of Cucumber). The primary causative agent of the disease is a representative of fungi of the genus Fusarium (Schlechtend.: Fr.), namely the fungus Fusarium oxysporum (Schlechtend.:Fr.) f. sp. cucumerinum (Owen) Snyder \& Hansen. This facultative parasite belongs to the division Ascomycota, subdivision Pezizomycotina, class Sordariomycetes, subclass Hypocreomycetidae, order Hypocreales, family Nectriaceae, genus Fusarium Link. The international universal disease code is FCU (Zitter et al., 1996). The pathogen affects cucumber plants in all stages of development. Infected seeds sown in the soil have low field germination. The hypocotyls of the affected sprouts rot, and they die even before coming out of the soil surface. The disease has a visual expression in two forms - directly wilting and rot of the root neck (Mihajlov, 1992). In the first form of disease symptoms, cotyledon leaves of the affected plant acquire a pale green color, lose turgor, wither and dry up within 2-3 days. In the second form of expression, root neck rot is most often observed in plants at excessive humidity and low soil temperature. With this course, the plant's root neck becomes thinner and rots, the stem becomes watery and translucent. In the future, such shoots break and fall (Yurina, 1984).

There are also two forms of damage in adult plants - direct wilting or growth inhibition (stunt, Gerlagh \& Blok, 1988). In this case, adult plants wither in the same way as shoots. Often individual shoots of the plant wither. Sometimes the affected plants do not die, remain stunt, their internodes become short, and their leaves become small. Fruits from such plants are also small, or do not form, inedible (Egel \& Martyn, 2007). The disease is spread through contaminated soil, plant remains, or seeds (Tkacheva, 2007).

Fusarium wilt causes especially great harm to cucumbers in frame area conditions with permanent cultivation (Gerlagh \& Blok, 1988). One recessive gene ( $F C u$ ) has been identified in the cucumber genome, which controls resistance trait to races 1 and 2 of this pathogen in plants (Gorbatenko, Holodnyak \& Shvartau, 2011). Considering that the cucumber crop in the frame area is the leading one, occupies significant areas and is often grown in a permanent crop, many pathogens accumulate in the soil, which inhibit the growth and development of plants negatively affect yields. The use of pesticides in the frame area leads to their accumulation in the soil and commercial fruits. Therefore, the creation of high-yielding cucumber hybrids of frame area with resistance to this disease is one of the world's essential modern tasks and domestic breeding (Yurina, 1984; Madamkin et al., 2010).

Bacteriosis, or angular bacterial spot disease of cucumber (English - Angular Leaf Spot of Cucumber). Pathogens - the bacterium Pseudomonas syringae pv. lachrymans (Smith \& Bryan) Young Dye \& Wilkie (синоніми - Bacterium lachrymans E.F. Smith and Bryan, Bacillus lachrymans (E.F Smith and Bryan) Holland, B. Burgeri Potebnia, Phytomonas lachrymans (E.F Smith and Bryan) Bergey et al., Pseudomonas lachrymans (E.F Smith and Bryan) Carsner).It belongs to the section of Gram-negative aerobic bacilli and cocci of the class Zymobacteria of the order Pseudomonadales of the family Pseudomonadaceae of the genus Pseudomonas Migula. According to the type of nutrition - a typical facultative parasite (hemibiotroph). The international universal disease code is PSL (Zitter, Hopkins \& Thomas, 1996). Bacterial spot disease is common in both open and frame area. Apart from cucumber, it can affect plants of melon. It appears on cotyledons (in light brown spots), leaves, stems, and fruits. On the leaves, oily angular spots first appear, limited by the small veins of the leaf. On the underside, when the air humidity is high, they are 
covered with yellowish droplets containing many bacteria. Later, the spots dry up, the tissue between the small veins falls out, the leaves become holey. With a firm lesion, the small veins themselves remain from the leaves. On the fruits, stems, and petioles of leaves, small watery spots first appear, which quickly increase in size and sink in the form of ulcers. Bacteria overwinter on plant remains in the soil (Agrios, 2005).

It is proved that the main infectious beginning from seed disease; its intensity is directly related to weather and climatic conditions. Usually, the first symptoms in the field are recorded from July to the end of the plants' growing season. During the growing season, bacteria are passively spread by wind, rain, irrigation water, and insects, in particular melon aphids, thrips, and spider mites, are the active vector of distribution (Kritzman \& Zutra, 1983). Dry and hot weather can correct the intensity of its development and distribution in agrocenoses of open-ground cucumber (Bedlan, 1986; Rai, 2008).

One recessive $\mathrm{psl}(\mathrm{pl})$ gene has been identified in the cucumber genome, which monogenously controls the cucumber plant's resistance to angular bacterial spot disease (Bedlan, 1986; Rai, 2008). Thus, the analyzed literature sources have shown that the critical phase of this vegetable crop in the phytosanitary aspect is the phase of mass fruiting, when using chemical and biological plant protection products, without violating sanitary and hygienic standards, becomes extremely difficult. Cucumber is consumed fresh, usually unripe. Fruits are harvested every 2-4 days, while the minimum waiting time for most allowed using biological and chemical preparations ranges from 7 to 20 days (Sergiyenko, 2003).

As the main conclusion, we will note that taking into account global trends and trends in breeding theory and practice, the fundamental task for Ukrainian scientists today is to obtain initial material of cucumber resistant to downy mildew, including gherkin cucumbers, by working out schemes of immunological, statistical and hybrid analyses. This will allow selecting valuable resistant initial parental material (genotypes) for varietal and heterotic breeding, harmoniously combining a complex of valuable approbatory and economic characteristics, and effectively using it in the breeding process.

\section{Conclusions}

Due to the global climate changes, the cultivation of varieties and hybrids of gherkin-type cucumbers (early ripening) has become attractive in commercial vegetable growing in Ukraine. The main advantage of which, in comparison with samples of the semi-late and medium ripening group, is the genetically controlled size of the Gherkin fruit - no more than $12 \mathrm{~cm}$, the compact habitus of the plant (with short runners), the maximum commercial yield on irrigation -19-23 t/ha (with twice-repeated crop rotation), with drip irrigation - 45-50 t/ha

At the same time, scientists have proved that introducing complex (integrated) systems into production, which expect the biologization of protection with its transfer to an ecological and economic basis, is recognized as the most promising today. We suggested that it is the use of resistant varieties (hybrids) in such integrated systems that provides the highest economic effect. The analyzed literature sources allowed us to establish a general and zonal list of the most common diseases of open-ground cucumber both in the research region and worldwide. We determined that diseases such as downy mildew, powdery mildew, fusarium wilt, angular bacterial spot disease, and anthracnose are always present on cucumbers under open ground conditions. Today, downy mildew of cucumber (pumpkin crops) in the open ground is widespread on all continents and geographical zones of cultivation - in Western, Central and Eastern Europe, Asia, Africa, North America, the Far, and the Middle East.

\section{References}

Adam, D.C. (2010). Studies on Resistance to Downy Mildew in Cucumber (Cucumis sativus L.) Caused by Pseudoperonospora cubensis: A thesis submitted to the Graduate Faculty of North Carolina State University in partial fulfillment of the requirements for the Degree of Master of Science. Horticultural Science Raleigh, North Carolina.

Agrios, G. (2005). Plant Pathology (Plant Disease Epidemiology). Elsevier Academic Press, 265-291.

Aleksashin V.I, Andreeva R.A, Antonov Yu.P. (1984). Ovoshevodstvo otkrytogo grunta. Moscow (In Russian).

Alekseeva, K.L. (1984). Ekologicheski bezopasnye priemy zashity ogurca ot boleznej v plenochnyh teplicah (rukovodstvo). Moscow, Rosselhozakademiya, GNU VNIIO (in Russian)

Autko, A.A. (2004). V mire ovoshej. Minsk, UP Tehnoprint (in Russian).

Avtorskie semena ovoshnyh kultur (ogurec) LTD "Selekcionno semenovodcheskaya forma Manul” (2008). Moscow (in Russian)

Azbuka ogorodnika. A.S. Bolotskih (Ed.). Kiyv, Urozhaj (in Russian).

Babadoost, M., Weinzieri, R.A. \& Masiunas, J.B. (2004). Identifying and Managing Cucurbit Pests. University of Illinois, 4-23.

Bailey J.A. et al. (1992). Infection strategies of Colletotrichum species. Colletotrichum: biology, pathology and control. ARS.

Bedlan, G. (1986). Under den Falschen Mehlau der Jurken. Pflanzenshutz, 4, 10-15.

Bilik, M.O. \& Kulyeshov, A.V. (2006). Praktikum z fitosanitarnogo monitoringu i prognozu. Harkiv, HNAU (in Ukrainian).

Blinova, T.P. (2005). Ispolzovanie provokacionnogo fona v selekcii ogurca na ustojchivost k lozhnoj muchnistoj rose. Ovoshebahchevye kultury i kartofel. Tiraspol, Tipar (in Russian).

Bolotskih, A.S. (2002). Ogurcy. Harkov, Folio(in Russian).

Bondarenko, S.V. \& Solodovnik, L.D. (2012). Polimorfizm kolekcijnogo ta selekcijnogo materialu ogirka kornishonnogo tipu za kompleksom oznak. Ovochivnictvo i bashtannictvo, 58, 50-57. (in Ukrainian).

Bondarenko, S.V. (2011). Ogirok: suchasnij fitosanitarnij stan ta metodi zahistu vid hvorob. Visnik HNAU im. V.V. Dokuchayeva. Ser. “Tehnichni, silskogospodarski, ekonomichni nauki", 6(1), 32-42 (in Ukrainian).

Bondarenko, S.V. (2012). Urazhenist ogirka nespravzhnoyu boroshnistoyu rosoyu (Pseudoperonospora cubensis Rostow). Proceed. Int. Sci. Conf. "Ovochivnictvo Ukrayini. Naukove zabezpechennya i rezervi zbilshennya virobnictva tovarnoyi produkciyi ta nasinnya", Merefa, NAAN, IOB. Kharkiv, Pleyada, 12-14 (in Ukrainian).

Bondarenko, S.V. (2013). Imunologichnij rozpodil selekcijnogo materialu ogirka kornishonnogo tipu za rivnem trivaloyi stijkosti do peronosporozu. Proceed. Int. Sc. Conf. “Pidvishennya stijkosti roslin do hvorob i ekstremalnih umov seredovisha v zv'yazku iz zadachami selekciyi". Kharkiv, Institut roslinnictva im. V.Ya. Yur'yeva. Kharkiv, Pleyada, 47 (in Ukrainian). 
Bondarenko, S.V. (2013). Rezultaty ocenki ustojchivosti k peronosporozu linejnogo materiala ogurca kornishonnogo tipa. Proceed. Int. Sc. Conf. "Selekciya i tehnologichni innovaciyi v ovochivnictvi, rezervi zbilshennya virobnictva produkciyi ta nasinnya", Merefa, NAAN, IOB. Harkiv, Pleyada, 17-18 (in Russian).

Bondarenko, S.V., Chernenko, V.L. \& Sergienko, O.V. (2013). Rezultaty ocenki ishodnogo materiala ogurca kornishonnogo tipa po priznaku ustojchivosti k peronosporozu (Pseudoperonospora cubensis (Berk. \& M.A.Curtis) Rostovtsev). Ovochivnictvo i bashtannictvo, 59, $251-$ 264 (in Russian).

Brunelli, A. \& Dawi R. (1987). La peronospora delta Cucurbitause. Informatori fitopatologica, 4, 17-21.

Buriev, H.Ch. et al. (2004). Ustojchivost sortoobrazcov ogurca k boleznyam. Zashita i karantin rastenij, 6, 47 (in Russian).

Celetti, M. \& Roddy, E. (2011). Downy Mildew in Cucurbits. Agricultural Information Contact Centre.

Chaban, V.S. (1993). Epifitotiya nespravzhnoyi boroshnistoyi rosi ogirka na Ukrayini ta mozhlivi shlyahi yiyi podolannya. Zahist i karantin roslin, 40, 18-19 (in Ukrainian).

Chaban, V.S. et al. (2000). Optimization of chemical control of Pseudoperonospora cubensis on cucumber in Ukraine. EPPO Bulletin, 30(2), 213215.

Chaudhry, S.U., Iqbal, J. \& Mustafa, A. (2009). Efficacy of different fungicides for the control of Downy mildew of cucumber. The Journal of Animal \& Plant Sciences, 19(4), 202-204.

Chernenko, V.L. et al. (2013). Osobennosti vzaimosvyazi osnovnyh kachestvenyh i kolichestvennyh priznakov s vredonosnostyu peronosporoza u ogurca kornishonnogo tipa. Visnik HNAU im. V.V. Dokuchayeva. Ser. "Fitopatologiya ta entomologiya”, 10, 179-185 (in Russian).

Chernenko, V.L., Sergienko, O.V. \& Bondarenko S.V. (2014). Zavisimost hozyajstvenno - cennyh priznakov ogurca kornishonnogo tipa ot ustojchivosti k peronosporozu. Zashita i karantin rastenij, 10, 44-45. (in Russian)

Chistyakova, L.A. \& Biryukova, N.K. (2012). Ocenka selekcionnyh linij ogurca na ustojchivost k peronosporozu i muchnistoj rose. Gavrish, 1, 3841 (in Russian)

Chulkina, V.A. \& Chulkina, Yu.I. (1995). Upravlenie agroeko-sistemami v zashite rastenij. Novosibirsk (in Russian)

Chumakov, A.E. (1973). Nauchnye osnovy prognozirovaniya boleznej rastenij. Moscow, Kolos (in Russian)

Cohen, Y. \& Rubin, A. (2012). Mating type and sexual reproduction of Pseudoperonospora cubensis, the downy mildew agent of cucurbits. Eur J. Plant Pathol, 132, 577-592.

Cohen, Y. (1977). The combined effects of temperature, leaf wetness, and inoculum concentration on infection of cucumbers with Pseudoperonospora cubensis. Canadian Journal of Botany, 55, 1478-1487.

Colucci, S.J. \& Wehner, C.T. (2006). The downy mildew epidemic of 2004 and 2005 in the Eastern United States. Cucurbitaceae, $403-410$.

Dhillon, N.P.S., Pushpinder, P.S. \& Ishiki K. (1999). Evaluation of landraces of cucumber (Cucumis sativus L.) for resistance to downy mildew (Pseudoperonospora cubensis). Plant Genetic Resources Newsletter, 119, 59-61.

Efimov, M.S., Sklyarevskaya, V.V. \& Olhovskaya, N.Ya. (1978). Lozhnaya muchnistaya rosa na Ukraine. Zashita rastenij, 12, 37. (in Russian)

Egel, D.S. \& Martyn, R.D. (2007). Fusarium wilt of watermelon and other cucurbits. The Plant Health Instructor, DOI: 10.1094/PHI-I-2007-0122-01.

Forsberg, A.S. (1986). Antrehh av blandmodel Pseudoperonospora cubensis in svenska gurklaft sensomaren. Vaxtskyddsnotigar, 50(1), 17-19.

Garibova, L.V. \& Lekomceva, S.N. (2005). Osnovy mikologii: morfologiya i sistematika gribov i gribopodobnyh organizmov (uchebnoe posobie). Moscow, Tovarishestvo nauchnyh izdanij KMK (in Russian).

Gavrish, S.F. (2001). Sostoyanie i perspektivy selekcii ovoshnyh kultur v Rossii. Selekciya i semenovodstvo s.-h. kultur v Rossii v rynochnyh usloviyah (in Russian).

Gerlagh, M. \& Blok, W.J. (1988). Fusarium oxysporum f.sp. cucurbitacearum n.f. embracing all formae speciales of $F$. oxysporum attacking cucurbitaceous crops. Netherlands Journal of Plant Pathology, 94(1), 17-31.

Gorbatenko, I.Yu., Holodnyak, O.G. \& Shvartau, V.V (2011). Ogirok. geni stijkosti. Kiyiv, Logos (in Ukrainian)

Gorohovskij, V.F. (2002). Metod ocenki porazheniya ogurca peronosporozom. Selekciya i semenovodstvo, 1, 27-28 (in Russian).

Gorohovskij, V.F. (2005). Soderzhanie pigmentov v listyah ogurca pri porazhenii rastenij peronosporozom. Ovoshebahchevye kultury i kartofel. Tiraspol, Tipar, 105-107 (in Russian)

Gorova, T.K. \& Yakovenko, K.I. (2001). Suchasni metodi selekciyi ovochevih i bashtannih kultur. Harkiv, 311-362 (in Ukrainian)

Granke, L.L. \& Hausbeck, M.K. (1995). Dynamics of Pseudoperonospora cubensis sporangia in commercial cucurbit fields in Michigan. Plant Diseases, 6, 1392-1400.

Grinko, N.N. \& Zherdeckaya, T.M. (1991). Peronosporoz ogurca. Minsk (in Russian)

Jeorgopoulos, S.J. \& Skylakakis, J. (1986). Jenetic variability in the fuhgi and the problem of fungicide resistence. Crop. Prot, 5, $299-305$.

Kartashov, I.A. \& Kazakova, V.S. (1988). Izuchenie ustojchivosti k boleznyam sortov ogurca dlya industrialnoj tehnologi vozdelyvaniya. Zashita rastenij ot vreditelej, boleznej i sornyh rastenij. Stavropol, 57-59 (in Russian)

Kirichenko, V.V. \& Petrenkova, V.P. (2012). Osnovi selekciyi polovih kultur na stijkist do shkidlivih organizmiv: navchalnij posibnik; NAAN. Harkiv, In-t roslinnictva im. V.Ya. Yur'yeva (in Ukrainian)

Kritzman, G. \& Zutra, D. (1983). Systemic movement of Pseudomonas syringae pv. lachrymans in the stem, leaves, fruits, and seeds of cucumber. Canadian Journal of Plant Pathology, 5(4), 273-278.

Kupalova S.A., Bolotskih A.S. (1989). Sposob poseva i shemy razmesheniya rastenij ogurca, vyrashivaemogo na semena. Intensivnye tehnologii vozdelyvaniya plodovyh i ovoshnyh rastenij. Kharkiv, 81-85.

Laser, T., Manke, M. \& Frurynska, J. (1988). Masowe wystapienil drzyba Pseudoperonospora cubensis na ogurka w poise. Rorl. Ar. Posnaniu Ogrod, 4, 79-87.

Lebeda, A. \& Urban, J. (2004). Distribution, harmfulness and pathogenic variability of cucurbit downy mildew in the czech republic. Acta fytotechnica et zootechnica, 7, 170-173.

Lebeda, A. \& Widrlechner, M.P. (2003). A set of Cucurbitaceae taxa for differentiation of Pseudoperonospora cubensis pathotypes. Journal of Plant Diseases and Protection, 110(4), 337-349.

Lindenthal, M. et al. (2005). Effect of downy mildew development on transpiration of cucumber leaves visualized by digital infrared thermography. Phytopathology, 95, 233-240.

Litvinov, S.S. et al. (2011). Metodika polevogo opyta v ovoshevodstve. Moscow, Rosselhozakademiya, GNU VNIIO (in Russian)

Madamkin, O.S. et al. (2010). Selekciya pcheloopylyaemogo ogurca na ustojchivost k peronosporozu. Ovoshi Rossii, 2, 18-21 (in Russian)

Mamchur, F.I. (1988). Ovochi i frukti v nashomu harchuvanni. Uzhgorod: Karpati (in Ukrainian)

Markov, I. (2010). Peronosporoz ogurca. Ovoshevodstvo, 8. Available from: http://ovoschevodstvo.com/journal/browse/201008/article/280/ (in Russian)

Maryutin, O., Onishenko, O. \& Maryutin, F. (2010). Cikli rozvitku osnovnih gribnih patogeniv hvorob ogirka v agrocenozah zakritogo gruntu. Available from: http://www.nbuv.gov.ua/portal/Chem_Biol/Vldau/Agr/2010_2/files/10moaocs.pdf (in Ukrainian)

McGrath, M.T. (2001). Fungicide Resistance in Cucurbit Powdery Mildew: Experiences and Challenges. Plant Disease, 85(3), $236-245$. 
Medany, M.A., Wadid, M.M. \& Abou Hadid, A.F. (1999). Cucumber fruit growth rate in relation to climate. Acta Hortic. (ISHS), $91,107-112$.

Mende, J. \& Krumdein, J. (1986). Ausbreitung und Modleicheit zur Bekampfung des Falscher Mebetaus ser Jurke in der DDR. Jartenbau, 6(33), $170-172$.

Mihajlov, Yu.A. (1992). Peronosporoz ogurca i obosnovanie mer zashity ot bolezni v Levoberezhnoj Lesostepi Ukrainy. Thesis of Doctoral Dissertation. Kharkiv (in Russian)

Mitchell, M.N. et al. (2011). Genetic and pathogenic relatedness of Pseudoperonospora cubensis and P. humuli. Phytopathology, 101, 805-818.

Nalobova, V.L. (1998). Organotropnaya i ontogeneticheskaya predraspo-lozhennost rastenij ogurca k porazheniyu boleznyami. Ovoshevodstvo, 10, 69-76 (in Russian)

Nalobova, V.L. (2004). Vidovoj sostav i osobennosti ekologii gribov - vozbuditelej boleznej ogurca. Vesci Nacyyanalnaj Akademii navuk Belarusi. Seryya biyalagichnyh navuk, 2, 30-34 (in Russian)

Nalobova, V.L. (2005). Lozhnaya muchnistaya rosa ogurca (Peronospora cubensis (Begk. et Curt.) Rostowsz.) i intensivnost ee proyavleniya v respublike Belarus. Vesci nacyyanalnaj akademii navuk Belarusi, 2, 61-63 (in Russian)

Nalobova, V.L. (2005). Selekciya ogurca na ustojchivost k boleznyam. Minsk: Belprint (in Russian)

Nalobova, V.L. (2008). Podbor ishodnogo materiala dlya selekcii korotkoplodnyh sortov i gibridov ogurca kornishonnogo tipa. Ovoshevodstvo, 14, 105-110. (in Russian)

Naumov, N.A. (1931). Bolezni ovoshnyh i sadovyh rastenij (s osnovami obshej fitopatologii). Moskva, Selhozizdat, $257-258$ (in Russian)

Ojiambo, P.S., Paul, P.A. \& Holmes, G.J. (1997). A Quantitative Review of Fungicide Efficacy for Managing Downy Mildew in Cucurbits. Phytopathology, 100(10), 1066-1076.

Petrenko, M.P. \& Poznyak, O.V. (2007). Stvorennya gibridiv ogirka Nizhinskogo sortotipu na DS "Mayak" IOB UAAN. Ovochivnictvo i bashtannictvo, 53, 124-128 (in Ukrainian)

Priroda Ukrayini ta yiyi ohorona. (1975). Kiyiv: Politvidav (in Ukrainian).

Prosalkova, I.A. (1994). Peronosporoz ogurca. Zashita rastenij, 5, 24-25 (in Russian)

Rai, M. (2008). Cucurbit research in India: a retrospect. Cucurbitaceae 2008. Proceed. Xth EUCARPIA meeting on genetics and breedingof Cucurbitaceae. Pitrat M. (Ed.). INRA, Avignon (France), May 21-24th, 2008, 285-293.

Robaka, J. (2001). An Attempt at Integrated Control of Cucumber Downy Mildew (Pseudoperonospora cubensis). Journal of Vegetable Crop Production, 2 (2), 21-32.

Sanwen Huang et al. (2009). The genome of the cucumber, Cucumis sativus L. Nature Genetics, № 41, 1275-1281.

Sergiyenko, V.G. (2003). Sposobi zmenshennya pesticidnogo navantazhennya pri zahisti ogirka vid nespravzhnoyi boroshnistoyi rosi. Zahist i karantin roslin, 49, 111-120 (in Ukrainian)

Shetty, N.V. et al. (2002). Evidence for downy mildew races in Cucumber tested in Asia, Europe and North America. Scientia Horticulturae, 94, 231-239.

Skripnik, H.B. \& Lopotun, N.L. (2003). Poshuk dzherel stijkosti proti zbudnika nespravzhnoyi boroshnistoyi rosi ogirka. Zahist i karantin roslin, 49, 168-174. (in Ukrainian)

Skripnik, H.B. (2000). Struktura populyaciyi zbudnika nespravzhnoyi boroshnistoyi rosi ogirka. Zahist i karantin roslin, 46, 92-95 (in Ukrainian)

Sokolov, Yu.V. (2003). Muchnistaya rosa tykvennyh kultur: vredonosnost, biologiya vozbuditelya i istochniki ustojchivosti. Bahchevodstvo v Rossii (problemy pervichnogo semenovodstva). Proceed. Int. Sc. Conf. "Rossijskij arbuz", 28-29.08.2003, 58-64 (in Russian)

Stancheva, J. (2005). Atlas boleznej selskohoshyajstvennyh kultur (bolezni ovoshnyh kultur). Sofiya-Moscow, Pensoft, 89-111 (in Russian)

Strajstar, E.M. (1991). Sozdanie ishodnogo materiala dlya selekcii ogurca na ustojchivost k lozhnoj muchnistoj rose i drugie cennye priznaki. Thesis of Doctoral Dissertation. Leningrad (in Russian)

Summer, D.R. \& Rhafar, S.C. (1987). Control of foliar diseases of cucumber with resistant cultivars abd fungicides. Appl. Arg. Res., 5, 324-329.

Timchenko, V.J. \& Mihajlov, Yu.A. (1989). Biologicheskie osobennosti vozbuditelya lozhnoj muchnistoj rosy ogurca. Zashita rastenij, 3, 42-43.

Tkacheva, A.A. (2007). Metody in vitro v selekcii ogurca (Cucumis sativus L.) na ustojchivost k fuzariozu. Thesis of Doctoral Dissertation. Moscow (in Russian)

Varady, C. \& Ducort, V. (1985). Le mildion du concombra. Rev. Suisse Arborie Hortic., 2(17), 103-106.

Vitchenko, E.F. \& Meleshkina, T.N. (1991). Vyvedenie sortov i gibridov ogurca, ustojchivyh k peronosporozu. Selekciya, semenovodstvo i agrotehnika ovoshnyh kultur. Novosibirsk (in Russian).

Walters, D. et al. (2005). Induced resistance for plant disease control: Maximizing the efficacy of resistance elicitors. Phytopathology, 95, 13681373.

Wehner, T.C. \& Shetty, N.V. (1997). Downy mildew resistance of the cucumber germplasm collection in North Carolina field tests. Crop. Sci., 37, $1331-1340$.

Wu, S.Q. (1994).Integrated management of cucumber diseases in greenhouse. Bulletin of Agricultural Science and Technology, 2, 24.

Yachevskij, A.A. (1929). Spravochnik fitopatologicheskih nablyudenij, Leningrad, 133-139 (in Russian)

Yakubickaya, T.S. et al. (1987). Ogurcy. Minsk, Uradzhaj (in Russian)

Yarovij, G.I. (2006). Suchasnij stan i perspektivi rozvitku ovochivnictva v Ukrayini. Ovochivnictvo i bashtannictvo: mizhvid. temat. nauk. zb. Harkiv, 52, 3-14 (in Ukrainian)

Yarovij, G.I., Kulyeshov, A.V. \& Batova, O.M. (2010). Shlyahi udoskonalennya meteopatologichnogo metodu prognozuvannya hvorob roslin. Visnik HNAU. Seriya "Fitopatologiya ta entomologiya", 1, 115-120 (in Ukrainian)

Yurina, O.V. (1984). Selekciya ogurca na ustojchivost k boleznyam v Nechernozyomnoj zone SSSR. Selekciya na ustojchivost k osnovnym zabolevaniyam ovoshnyh kultur: Sb. nauch. trudov VNIISSOK. Moscow, 41-46. (in Russian)

Zherdeckaya, T.N. (1990). Vliyanie uvlazhneniya listev na razvitie lozhnoj muchnistoj rosy ogurca. Biologicheskij metod zashity rastenij. Minsk (in Russian)

Zitter, T.A., Hopkins, D.L. \& Thomas, C.E. (1996). Compendium of Cucurbit Diseases, University of Illinois APS Press, 66, 25-27.

\section{Citation:}

Bondarenko, S.V., Stankevych, S.V., Matsyura, A.V., Zhukova, L.V., Zabrodina, I.V., Rysenko, M.M., Golovan, L.V., Romanov, O.V., Romanova, T.A., Novosad, K.B., Klymenko, I.V., Ye.Yu. Kucherenko, Ye.Yu., Zviahintseva, A.M. (2021). Major cucumber diseases and the crop immunity. Ukrainian Journal of Ecology, 11 (1), 46-54.

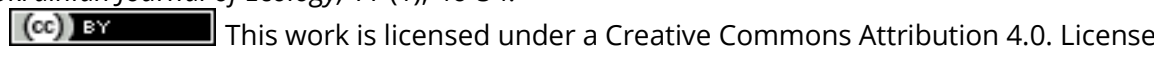

